\title{
A CRISE DO CONCEITO DE GENE
}

\author{
João Paullo Uchoa Zica \\ Graduando em Filosofia pela Universidade de Brasília (UnB)
}

\begin{abstract}
RESUMO
O conceito de gene, tal como proposto no decorrer do século XX, parece estar atravessando um dos mais interessantes e complicados momentos pelos quais os termos científicos por vezes atravessam: a revisão dos conceitos e termos nos quais se apoia. Para compreender este delicado - e excitante momento, precisamos compreender a história por de trás do desenvolvimento do conceito que atualmente é utilizado nas ciências biológicas. Para tanto, partiremos de Mendel e sua solitária aventura científica, que apenas postumamente foi reconhecida por sua vital contribuição para o desenvolvimento da ciência, passando pela disputa da compreensão dos processos de hereditariedade no início do século XX, pelos avanços que permitiram que o século passando fosse chamado de "o século do gene" e, finalmente, chegando aos avanços e limites que foram vislumbrados após o sucesso do inicialmente controverso Projeto Genoma Humano.
\end{abstract}

Palavras-chave: Gene, Filosofia da Biologia, Revisão Conceitual, Conceito Clássico de Gene.

\begin{abstract}
O conceito de gene, tal como proposto no decorrer do século XX, parece estar atravessando um dos mais interessantes e complicados momentos pelos quais os termos científicos por vezes atravessam: a revisão dos conceitos e termos nos quais se apoia. Para compreender este delicado - e excitante momento, precisamos compreender a história por de trás do desenvolvimento do conceito que atualmente é utilizado nas ciências biológicas. Para tanto, partiremos de Mendel e sua solitária aventura científica, que apenas postumamente foi reconhecida por sua vital contribuição para o desenvolvimento da ciência, passando pela disputa da compreensão dos processos de hereditariedade no início do século XX, pelos avanços que permitiram que o século passando fosse chamado de "o século do gene" e, finalmente, chegando aos avanços e limites que foram vislumbrados após o sucesso do inicialmente controverso Projeto Genoma Humano.
\end{abstract}

Key-words: Gene, Philosophy of Biology, Conceptual Review, Classic Concept of Gene.

\section{Mendel: $O$ grande precursor}

A noção de que determinadas características presentes em um organismo são passadas para seus descendentes parece ser antiga na história da humanidade, sendo difícil precisar exatamente quando este fenômeno foi constatado ou registrado pela primeira vez. Porém, mesmo sendo um fenômeno reconhecido desde tempos remotos, apenas na segunda metade do século XIX a ciência deu um passo fundamental - que passou despercebido por cerca de 
meio século - na descoberta do processo por trás da hereditariedade de determinadas características. Gregor Mendel (1822-1884), um monge agostiniano com relativo conhecimento e instrução na área de física experimental de sua época (CRUZ, 2011, p.203), interessado na constância de características que se manifestavam e se mantinham mesmo no cruzamento de alguns exemplares híbridos, desenvolveu a grande teoria que mais tarde seria reconhecida como fundamental para o desenvolvimento das ciências biológicas e para o estabelecimento do conceito de gene ${ }^{1}$. Cabe ressaltar desde já que o termo 'gene' não foi desenvolvido por Mendel (a criação da palavra 'gene' só se daria em 1909), sendo que para se referir ao elemento causador da hereditariedade foram utilizados em seus estudos os termos 'fator recessivo' e 'fator dominante'.

Assim, devemos apontar desde já que o problema que atualmente se apresenta para o conceito de gene, tratado nas próximas linhas, deriva em parte, justamente da (implícita) noção mendeliana de que existe uma unidade física específica, um único locus, responsável pelo processo de hereditariedade. Com o desenvolvimento da genética do século XX, a intensificação dos estudos acabou por nos levar a ideia de que haveria uma unidade de função, informação e estrutura responsável pelo processo em questão, porém, como veremos mais a frente, será justamente essa noção de uma função, uma informação, uma estrutura (1:1:1) que estará em crise no início do século XXI (JOAQUIM e EL-HANI, 2010, p.7).

$\mathrm{O}$ experimento inicialmente elaborado por Mendel teve como objetivo inicial a observação da hereditariedade de determinadas características de leguminosas do gênero Pisum (ervilhas) através da hibridização de plantas com características diferentes. $\mathrm{O}$ interessante a se notar é que, em seu experimento, Mendel descreveu antecipadamente isto é, antes de obter os resultados, as características manifestadas em cada uma das plantas que utilizaria, buscando desta forma tornar mais claro o objeto de seus estudos. Assim, tinha-se a vantagem nos experimentos em questão de permitir especificar anteriormente quais as características que se mantinham de geração para geração e quais eram suprimidas, evitando assim a possível acusação de que estaria manipulando dados anteriores para embasarem os resultados. Outra grande vantagem dos experimentos mendelianos eram as inovações apresentadas, tais como: uso de experimentos-controle separados dentro de estufas e o uso de matemática estatística descrever as ocorrências dos chamados fatores dominantes e recessivos (CRUZ, 2011, p.203). Inicialmente, utilizando o cruzamento entre leguminosas com sementes

\footnotetext{
${ }^{1}$ A teoria desenvolvida por Mendel não foi aceita sem que tenham ocorrido alterações, porém, em suas linhas principais, boa parte foi mantida pelos 'geneticistas' posteriores.
} 
enrugadas (parentais) ${ }^{2}$ e sementes redondas e lisas (parentais), notou-se que a primeira geração (híbridos) sempre se apresentava como redonda e lisa, aparentando assim que seriam tais como as sementes redondas e lisas parentais quando cruzadas entre si. Porém, nas resultantes deste cruzamento feito entre sementes híbridas (primeira geração) notava-se a proporção de 3:1 respectivamente das características 'redonda lisa' e 'enrugada' (segunda geração). As sementes desta geração que apresentavam a característica 'enrugada' comportavam-se em cruzamentos posteriores tal como uma semente parental, não sendo observado em suas descendências o surgimento da característica 'redonda e lisa'. Por sua vez, as sementes desta mesma geração (segunda) apresentavam características diferentes quando cruzadas entre si. Tomando as sementes desta segunda geração se obtêm na terceira geração uma proporção de 1:2:1 das seguintes características: 'redonda e lisa (parental)'; 'redonda e lisa (híbrida)'; 'enrugada (parental)'.

Apesar de toda a rigorosidade e do espantoso avanço que trazia a pesquisa de Mendel, ela acabou por padecer do mal que alguns dos avanços científicos trazem consigo: serem reconhecidos apenas após a morte de seu autor. Mesmo tendo sido publicada em 1866 e apresentada em duas conferências da Sociedade de História Natural de Brno, no ano anterior ao de sua publicação, a teoria mendeliana só seria devidamente reconhecida em sua importância a partir do ano de 1900. A falta do devido reconhecimento de seus contemporâneos parece estar até os dias de hoje sem uma explicação satisfatória, porém algumas razões podem indicar para parte do problema (CRUZ, 2011, p.204): a resistência de grande parte da comunidade às teorias evolutivas apresentadas por Darwin e Wallace em anos anteriores $^{3}$; possível incompreensão dos resultados obtidos por Mendel; preconceito contra as experiências científicas de um monge; pouco esforço do próprio autor em divulgar seus resultados; resistências religiosas ou filosóficas etc.

\footnotetext{
${ }^{2}$ Os termos 1) 'parental' e 2) 'híbrido' referem-se respectivamente a: 1) não apresenta em sua descendência qualquer exemplar com características híbridas e ; 2) apresenta em sua descendência exemplares com características hibridas e parentais. Simplificando: uma vez que seja feito o cruzamento com sementes parentais somente serão encontradas exemplares com as mesmas características de seus genitores diretos, entretanto nas sementes híbridas é possível o surgimento de características que estavam latentes e não se manifestavam em seus genitores.

${ }^{3}$ Esse período, que abrange as últimas décadas do século XIX e as primeiras do XX, ficou conhecido como 'eclipse do darwinismo'. Nesse período houve uma grande resistência à teoria adaptacionista, ocorrendo embates não somente com determinados setores religiosos que viam no darwinismo uma ofensa a criação divina, mas também dentro da área científica que permanecia às voltas com os novos dados proporcionados pela paleontologia e geologia. Duas explicações se apresentavam como as principais concorrentes ao adaptacionismo nesse período: Os Neolamarckistas e Ortogeneticistas.
} 


\section{Século XX: O nascimento do conceito e o início de sua crise}

O século XX foi largamente reconhecido como o período da história humana no qual as diferentes áreas do conhecimento científico avançaram de modo dinâmico e constante. A biologia, ciência que já havia se estabelecido como tal durante os séculos XVIII e XIX, teve um papel central em boa parte dos avanços ocorridos nesse período, e, dentro dessa ciência, um dos campos que mostrou maior avanço foi o campo da genética (VICUÑA, 2011, p.197). Como vimos anteriormente, já no início da segunda metade do século XIX Mendel havia lançado as bases para a compreensão do processo de hereditariedade, porém, devido a vários fatores, essas bases foram sistematicamente ignoradas até o início do século seguinte. Quando o século XX iniciou tínhamos um quadro geral com várias teorias concorrentes. Entre essas várias teorias concorrentes uma das que mais se destacou, chegando até mesmo a alguns de seus defensores a repetirem independentemente algumas das descobertas de Mendel, foi a teoria da pangênese ${ }^{4}$. Após o trabalho desenvolvido por Hugo de Vries, publicado no ano de 1889, no livro Intracelluar Pangenesis, esta teoria ganhou novo fôlego e esteve por um longo período como uma das possibilidades para explicação da hereditariedade. As duas teorias, apesar de possuírem características comuns (CRUZ, 2011, p.217), entraram em choque e, assim como ocorre em diferentes áreas da ciência, neste período ocorreu um intenso debate para saber qual seria a teoria vencedora. Esses acontecimentos, que até hoje parecem não totalmente esclarecidos, formam uma série de casos que levam alguns historiadores da ciência a duvidar da honestidade intelectual de Vries em relação à sua dívida com a teoria mendeliana (idem, p. 221).

Apesar do debate acerca da honestidade de Vries, é indiscutível a sua contribuição para o avanço das ciências biológicas. Para tanto, podemos tomar como exemplo a história por trás do termo 'gene'. Até o inicio do século XX o termo utilizado para se referir à 'entidade' causadora da hereditariedade era 'caráter de unidade', foi apenas em 1909 que o dinamarquês Wilhelm Johanssen cunhou o termo 'gene' ${ }^{6}$, e boa parte do trabalho apresentado

\footnotetext{
${ }^{4}$ Apesar das teorias de Mendel e Darwin terem sido desenvolvidas em períodos praticamente concomitantes, a base utilizada por Darwin para justificar a hereditariedade foi a teoria da pangênese. De fato, Darwin publicou, em 1868, o livro "Variação de plantas e animais domesticados", onde defendia explicitamente o a teoria da pangênese.

5 Os termos 'fator dominante' e 'fator recessivo' não parecem ter sido adotados fortemente pela comunidade geneticista em nenhum período.

${ }^{6}$ A terminologia utilizada pelos geneticistas no inicio do século XX, apesar de não ser nosso foco, se apresenta como uma história interessante. Segundo Thomas Hunt Morgan, a terminologia utilizada pelos geneticistas foi considerada, por seus companheiros zoólogos e botânicos, como 'bárbara', não cabendo a rotina de um cientista.
} 
por Johanssem foi apresentado sob influência da teoria da pangênese, desenvolvida por Hugo de Vries. Nesse período, os estudos de Mendel já haviam sido resgatados e, além disso, os resultados obtidos através de sua teoria caminhavam cada vez mais em direção à proposta darwinista (CAPONI, 2011, p. 753). Embora nenhuma das teorias, darwinista ou mendeliana, estivesse plenamente aceita pela comunidade científica ${ }^{7}$, era cada vez mais comum que surgissem cientistas como Edmund Ford que as utilizassem para estudos e pesquisas, de fato, após este período tornou-se cada vez mais patente o alinhamento de Darwin e Mendel.

A concepção de gene neste período foi tomada, entre outras razões, por ter se apresentado como bastante útil, mas não necessariamente correspondente a alguma entidade real (VICUÑA, 2011, p.199). Assim, o estudo dos genes prosseguiu de modo satisfatório, especialmente após o uso da mosca fruta, Drosophilamelanogaster, nos estudos de Thomas Morgan, ter comprovado que a teoria mendeliana aplicava-se também à hereditariedade de animais ${ }^{8}$. O próprio Morgan, apesar de ter contribuído largamente para o desenvolvimento da genética, também contribuiu para a visão reducionista que veio a gerar a crise no conceito molecular clássico. A visão reducionista em questão se dá a partir da ideia de que o gene é uma unidade física específica (ou seja, não é apenas uma hipótese útil), com uma única função e com um único produto gênico, assim, chegamos à noção de 1:1:1. Nesse momento, creio que seja necessário explanarmos minimamente o que pode ser considerada a definição clássica de gene utilizada na maior parte do século XX. Tomando o conceito expresso no site oficial do National Human Genome Research Institute (NHGRI) temos a seguinte definição do conceito de gene: O gene é a unidade física básica da herança. "Os genes são transmitidos dos genitores para os descendentes e contêm a informação para características específicas. Genes são organizados, um após o outro, em estruturas chamadas cromossomos"9. Os problemas com a definição de gene se concentram em sua realidade ontológica, bem como na caracterização específica de suas funções e - se de fato não for uma entidade meramente instrumental - seus limites físicos como uma entidade específica. Até o inicio da década de 70

Curiosamente, Morgan em uma comum tentativa de prever o futuro, anunciou acertadamente que "sem dúvida essa é uma fase passageira". Para mais detalhes <http://ia700402.us.archive.org/13/items/mechanismofmende00morg/mechanismofmende00morg.pdf > a partir da página VII.

7 A teoria darwinista somente esteve plenamente estabelecida como o principal meio de pesquisa acerca da variedade de espécies a partir do período entre as décadas de 1930 e 1950. Durante o fim do século XIX e início do século XX boa parte deste trabalho estava alinhado com o trabalho de Georges Cuvier e a paleontologia comparada desenvolvida por ele. Parte deste trabalho pode ser exemplificado no lema "tracem filogenias e não identifiquem adaptações."

${ }^{8}$ Uma preocupação que cercou o próprio Mendel foi a de que sua teoria somente explicasse o sistema hereditário de determinadas espécies, notadamente, parte da resistências as teorias mendelianas se deram por este receio.

${ }^{9}$ Tradução própria. 
o conceito de gene - tal como o apresentado - não enfrentou grandes dificuldades, os avanços científicos ocorridos até então pareciam justamente vir a fortalecer a ideia de que o gene é uma entidade real, um locus. Uma das grandes contribuições para essa ideia foi a descoberta da estrutura do DNA, em 1953, por James Watson e Francis Cric, com a contribuição de Maurice Wilkins. Esta descoberta lhes rendeu o prêmio Nobel em 1962. Porém, em meados da década de 70 essa estabilidade acerca do conceito de gene começou a estremecer.

Um dos grandes problemas teve inicio com o estudo de bactérias entéricas ${ }^{10}$ responsáveis pela digestão da lactose. Em estudos da década de 60 notou-se que na ausência de lactose essas bactérias deixavam de ativar os genes responsáveis pela produção de enzimas digestoras do leite. Apesar de esta descoberta por si só parecer um tanto trivial, a partir dela notou-se que os genes podem existir em um estado inativo, ou seja, mesmo existindo, não necessariamente ele está interferindo ativamente no metabolismo. Outro grande problema surgiu em 1977, quando David Glover e David Hogness descobriram que a maior parte dos genes de eucariotos ${ }^{11}$ codificadores de RNA era interrompida, e, a partir de 1978, tendo as regiões interrompidas não codificadoras sido chamadas de exóns e as regiões codificadoras de íntrons $^{12}$ (JOAQUIM e EL-HANI, 2010, p.8). Com essa descoberta, surgiu o que posteriormente foi chamado de DNA-lixo ${ }^{13}$, ou seja, as regiões introgênicas por não serem codificantes não exerceriam nenhum tipo de função, e, portanto, sendo completamente descartáveis ${ }^{14}$.

Quanto ao produto dos genes, nos deparamos com, pelo menos, dois fenômenos interessantes: i) O splicing alternativo se apresenta como outro grande empecilho à definição

\footnotetext{
${ }^{10}$ Estas bactérias, constantemente relacionadas a algumas doenças, são encontradas no intestino de seres humanos e outros animais.

${ }^{11}$ São classificados como eucariotos os organismos que possuem um núcleo celular contendo toda, ou a maior parte, da informação genética do organismo. Desta forma, a membrana eucariótica mantêm o DNA e o RNA separo de outras partes da célula

${ }^{12}$ Esta definição tinha como finalidade separar o DNA-lixo do DNA que efetivamente codificaria o DNA, entretanto, como veremos, esta definição encontrou vários problemas, entre eles os genes aninhados.

${ }^{13}$ O chamado DNA-lixo, a despeito dessa caracterização inicial, se mostra cada vez mais interligado com a produção gênica: "Alguns estudos dos cromossomos 21 e 22 indicaram que grandes quantidades de DNA anteriormente tratado como lixo são de fato transcritas, mostrando que muito mais do que os éxons são transcritos no genoma. Podemos dizer que há menos distinções entre as regiões gênicas e as intergênicas do que se pensava anteriormente (...) Um aspecto interessante sobre as chamadas TARs (regiões transcricionalmente ativas) é que o número delas varia bastante entre as espécies, ao contrário do número de genes que, como sabemos, não varia muito. Humanos possuem números de genes semelhantes a outras espécies, mas números de TARs superiores. Com base nisso, tem-se concluído que as sequências podem ter um papel chave na explicação de diferenças entre as espécies e, portanto, o antigo "DNA-lixo" está muito longe de ser descartado de estudos futuros, na medida em que pode ter importante papel evolutivo" (JOAQUIM e EL-HANI, 2010, p.101)

${ }^{14} \mathrm{Um}$ dos problemas que surge ao se considerar essa região do DNA como descartável é que, curiosamente, essas regiões são mantidas sem grandes alterações ao longo do processo de seleção natural, sendo problemática a ideia de que apesar de ser inútil ela é mantida através das gerações sem grandes variações em sua estrutura.
} 
clássica de gene. Neste fenômeno temos a possibilidade de que um único gene produza mais de um tipo de proteína, ou seja, quebra-se a noção 1:1:1. Com ele temos a possibilidade que um número relativamente restrito de genes produza uma coleção bem maior de proteínas. Para se ter uma ideia da importância do splicing alternativo, é estimado que cerca de $75 \%$ de todas as proteínas do corpo humano sejam produzidas através desse fenômeno; ii) No sentido oposto ao splicing alternativo, temos a possibilidade de dois genes transcreverem um único RNA, ou seja, nesse processo temos uma proteína que foi resultado da ação de dois genes (VICUÑA, 2011, pp.203-4).

Apesar dos problemas explanados acima, no final do século XX tivemos o ápice da tentativa de compreensão do gene sob uma ótica reducionista ${ }^{15}$ : o Projeto Genoma Humano (PGH) e, em menor grau reducionista, a Enciclopédia dos Elementos do DNA (ENCODE). Como podemos ver:

Os defensores iniciais do sequenciamento do genoma humano falavam enfaticamente do Livro do Homem, querendo com isto dizer que se conhecêssemos a sequência total do genoma conheceríamos o funcionamento de nosso organismo. À proporção que o projeto desenvolveuse, a crença no tal livro foi esmaecendo, até que hoje ninguém mais fala dele. (CRUZ, 2011, p.277)

Em ambos os projetos, cada um incomensuravelmente impactante a seu modo ${ }^{16}$, tivemos a tentativa de compreender o funcionamento do ser humano basicamente a partir do que se acredita ser uma da estruturas mais básicas e elementares de todos os seres vivos - o gene. Porém, mesmo com o espantoso sucesso de ambos os projetos, a questão ontológica permaneceu e o conceito de gene continuou como uma questão aberta. A definição dada pelo Dr. Francis S. Collins, um dos fundadores NHGRI, apresentada nas linhas anteriores, carrega em si mesmo um dos problemas atuais acerca da estrutura do gene: "Genes são organizados, um após o outro, em estruturas chamadas cromossomos" (glossário, COLLINS). O problema em questão se dá com o conceito de íntron, pois com ele temos a possibilidade de encontrarmos genes aninhados ${ }^{17}$ (nested gene), o que permite que um gene esteja inteiramente

\footnotetext{
$15 \mathrm{O}$ pensamento reducionista em questão poderia ser resumido do seguinte modo: compreendendo-se o mecanismo de funcionamento das estruturas biológicas mais básicas de um determinado organismo, poderá se compreender o funcionamento de todo o sistema. Entre os perigos que surgem com a visão reducionista biológica, temos o exemplo mais extremado - embora se apresente como um reducionismo calcado em outros pressupostos - em Cesare Lombroso e seu "Homem Delinquente" determinado a partir de características físicas delatoras de inferioridade e tendências primitivas.

${ }^{16}$ Apesar de compreender que ambos os projetos possuem caráter reducionista, isso não significa de modo algum reconhecer o sucesso e eficácia exemplar de ambos os projetos, tão pouco deixar de reconhecer os grandes avanços científicos que foram possibilitados por estas iniciativas.

${ }^{17}$ Quando uma sequencia de codificação completa de um gene é encontrada dentro de outro gene, geralmente um íntron, este gene é definido como um gene aninhado.
} 
contido dentro do íntron de outro gene, tornando assim difícil delimitar sua estrutura e verificar sua localização (VICUÑA, 2011, p.204).

O século XX fechou-se sem concluir efetivamente a problemática acerca do gene; qual seria então o futuro deste conceito mediante estas - e outras - constatações de suas limitações? Seria o caso de abandonar o termo devido à dificuldade de encontrar estruturas exatamente correspondentes ao conceito clássico ou devemos de algum modo, como querem os menos céticos, reestruturar esse conceito para que possa ser salvo?

\section{Possibilidades e desafios no século XXI}

Atualmente encontramos uma grande variedade de tentativas de definição de gene para salvar a realidade ontológica deste, seja pela reformulação da noção de estrutura, seja pela noção de função ou pelo acréscimo de novas estruturas anteriormente ignoradas. A noção estrutural parece estar claramente ligada à boa parte das causas da atual crise, de modo que não se apresenta como uma via promissora e, a despeito disso, esta concepção está mais fortemente estabelecida não somente no senso-comum, mas também nos próprios acadêmicos (idem, p.212). Além disso, esta visão compromete-se desde o início com a existência real de um objeto que possuiria uma única estrutura ${ }^{18}$. Este comprometimento - que em última análise se dá em uma ligação com a concepção de 'fator' mendeliano - apesar de largamente defendido, não parece sensível aos avanços no campo genético que demonstram a insuficiência da concepção clássica, e, por fim, acabam cedendo mais espaço para aqueles que advogam em favor da extinção do conceito de gene.

A proposta da extinção do gene do vocabulário científico e cotidiano possui certos entraves que dificultam a sua completa adesão, fazendo com que parte da comunidade científica relute em abandonar um conceito que lhe é tão caro. Podemos tomar como princípio o simples fato de que este já é um termo chave no jargão científico. Tendo sido estabelecido ao longo de seu desenvolvimento uma série de conexões com vários outros conceitos, o que faria com que, em uma eventual abolição de seu uso, uma imensa parte do edifício conceitual das ciências biológicas viesse abaixo:

\footnotetext{
${ }^{18}$ De modo algum estamos apontando para a impossibilidade da realidade ontológica do conceito de 'gene', porém, comprometer-se completamente com este conceito quando existem claros sinais de problemas nos levaria, em último ponto, apenas a uma instrumentalização do conceito.
} 
Suponha-se, contudo, que rejeitemos a ideia de que os genes sejam unidades de transmissão e herança. O que perderíamos com isso? Certamente, precisaremos encontrar outras entidades na célula às quais possamos atribuir o papel de mediar a transmissão e a herança, já que genes serão entidades muito mais transitórias do que costumávamos pensar. (JOAQUIM e ELHANI, 2010, p.121).

Além disso, no caso de uma abolição completa, seria necessária a construção e solidificação de outro conceito que substituísse a explicação que atualmente o conceito de gene carrega consigo, o que nos levaria a uma nova disputa científica no surgimento de conceitos chave. Estas dificuldades, porém, não devem ser tratadas como barreiras. Se for o caso de uma real necessidade de abandono do termo 'gene', e nos negarmos a lidar com estas questões visando unicamente esquivar de complicações conceituais ou novos embates, correríamos o risco de abandonar um real debate acerca da ontologia do gene e passaríamos para um debate acerca da utilidade deste conceito dentro do discurso cientifico que visa explicar a realidade que o ser humano tem diante de $\mathrm{si}^{19}$. O modo que parece se apresentar como o mais honesto frente a essa crise é a tentativa de demonstrar que o conceito de gene ainda não tenha se esgotado, ou seja, que ainda lhe é possível a incorporação ou alteração de partes de seu conceito sem que seja completamente desfigurado.

Entre as várias tentativas de redefinir o conceito de gene, podemos encontrar definições que combinam parte da concepção estrutural e parte da concepção funcional; outras que expandem a estrutura do gene para abrigar também o que foi anteriormente chamado de DNA-lixo; algumas que preferem manter uma gama de definições para que possam ser utilizadas de acordo com o ponto pesquisado; outras que preferem definir gene como uma rede de operações biológicas com possibilidade de produção de vários resultados diferentes. Frente a todas estas propostas, podemos tomar como uma das mais interessantes a noção de que o gene não deve ser tratado como substantivo, mas como verbo. Nesse sentido, deveríamos deixar de buscar regiões que possam ser classificadas como genes, passando então a compreender que várias regiões do código genético poder "genear", ou seja, podem executar a função que atualmente é atribuída à entidade - com realidade ontológica - que chamamos de gene. Esta proposta, apresentada por JOAQUIM e EL-HANI parece ser extremamente

\footnotetext{
${ }^{19}$ A consequência de uma postura como essa seria o comprometimento com um uma visão antirrealista acerca da ciência, bem como o utilitarismo de conceitos e teorias cientificas. Teríamos ainda a possibilidade de impedirmos parte do desenvolvimento das ciências biológicas devido ao apego a um termo que não mais se apresenta capaz de lidar com os novos avanços de sua área, impedindo que uma nova compreensão, ou ainda uma possível revolução, viesse a surgir.
} 
promissora, tornando-se mais capaz de explicar os acontecimentos estudados pelas ciências biológicas $^{20}$.

A noção de que o gene deve ser compreendido a partir de seu caráter funcional pode lidar melhor com a variedade de produtos gênicos através do splicing alternativo, bem como adequar-se à problemática das regiões anteriormente consideradas DNA-lixo, mas que atualmente têm sua função revista. Outro grande ponto a favor dessa concepção, seria a melhor compreensão da relação entre o mRNA e o DNA. Neste aspecto, o DNA deixaria de ser o local onde o gene está, para ser o local no qual o mRNA produz os diferentes tipos de produtos gênicos, superando ainda a noção de que os genes existem e têm seu produto específico para a noção de que os genes precisam ser ativados. Logicamente, esta concepção não deixa de carregar suas problemáticas, trazendo dificuldades não apenas para a prática científica, mas também evidenciando o debate instrumentalista e realista. Por fim, cabe notar que a biologia, como boa parte das outras ciências, apesar dos vários tipos de problemas conceituais, epistemológicos ou ontológicos não está - e é bom que não esteja impossibilitada de fazer avanços e descobertas. Talvez estes avanços, característicos das ciências naturais, possam nos ajudar a solucionar as questões colocadas atualmente, ou, no mínimo, jogar nova luz sobre estas questões.

\section{Bibliografia}

CAPONI, Gustavo. Las raíces del programa adaptacionista. Scientiae Studia. v. 9, n.4. São Paulo. 2011. pp. 705-738.

La consolidación del programa adaptacionista. Scientiae Studia. v. 9, n.4.

São Paulo. 2011. pp. 739-775.

CRUZ, Waldenor Barbosa. Herança e evolução: Aventuras da biologia no século XX. In: SIMOM, Samuel (Org.). Um século de conhecimento. Brasília: Ed. Universidade de Brasília, 2011. pp.195-288.

FARIA, Felipe. A Revolução darwiniana na paleontologia e a ideia de progresso no processo evolutivo. Scientiae Studia. v. 10, n.2. São Paulo. 2012. pp. 297-326.

\footnotetext{
${ }^{20}$ Isso não significa que esta concepção não carrega consigo alguns problemas reconhecidos pelos próprios autores, tais como: a dificuldade de localização do gene já que este passaria a ser um processo; o gene passaria a não estar mais no DNA para apenas ser processado nele etc.
} 
JOAQUIM, Leyla Mariane; EL-HANI, Charbel Niño. A genética em transformação: crise e revisão do conceito de gene. Scientiae Studia. v. 8, n.1. São Paulo. 2010. pp. 93-128.

National Human Genome Research Institute. [online] Disponível na Internet via WWW. URL:<http://www.genome.gov/Glossary/> Último acesso em 27 de junho de 2013.

VICUÑA, Rafael. The evolving concept $\mathrm{f}$ the gene. In: The Scientific Legacy of the 20th Century. Vatican City: The Pontifical Academy of Sciences, 2011. pp.197-214. 